\title{
Soil properties under different land use systems of Mizoram, North East India
}

\author{
Chowlani Manpoong* \\ Department of Forestry, Mizoram University, Aizawl-796004, India \\ S.K. Tripathi \\ Department of Forestry, Mizoram University, Aizawl-796004, India \\ *Corresponding author. E-mail: chowlani18@gmail.com
}

\begin{abstract}
Changes in land use and improper soil management have led to severe land degradation around the globe through the modification in soil physicochemical and biological processes. This study aimed to assess the soil properties of different land use system types. Soil samples (0-15 cm depth) were collected from five land uses; Rubber Plantation (RP), Oil Palm Plantation (OPP), Bamboo Forest (BF), Fallow Land (FL) and Natural Forest (NF) and analyzed for bulk density, soil texture, soil $\mathrm{pH}$, soil moisture, soil carbon, total nitrogen, ammonium, nitrate, soil microbial biomass carbon, soil respiration. Soil pH was lower than 4.9 in all the sites indicating that the surface soil was highly acidic. Soil organic carbon (SOC) and total nitrogen (TN) values ranged from $2.02 \%$ to $2.81 \%$ and $0.22 \%$ to $0.3 \%$ respectively. Soil organic carbon (SOC), total nitrogen (TN) and soil microbial biomass (SMBC) were highly affected by soil moisture. $\mathrm{NH}_{4}^{+}-\mathrm{N}$ and $\mathrm{NO}_{3}^{-}-\mathrm{N}$ ranged from 5.6 $\mathrm{mg} \mathrm{kg}^{-1}$ to $10.2 \mathrm{mg} \mathrm{kg}^{-1}$ and $1.15 \mathrm{mg} \mathrm{kg}^{-1}$ to $2.81 \mathrm{mg} \mathrm{kg}^{-1}$ respectively. NF soils showed the maximum soil microbial biomass carbon (SMBC) whereas the minimum was observed in BF with values ranging from $340 \mathrm{mg} \mathrm{kg}^{-1}$ to $345 \mathrm{mg} \mathrm{kg}^{-1}$. Basal respiration was highest in RP (375 mg CO $\left.2 \mathrm{~m}^{-2} \mathrm{hr}^{-1}\right)$ and lowest in BF $\left(224 \mathrm{mg} \mathrm{CO}_{2} \mathrm{~m}^{-2} \mathrm{hr}^{-1}\right)$. The findings demonstrated significant effect $(p<0.05)$ of land use change on soil nutrient status and organic matter. Findings also indicated that land use change deteriorated native soil physicochemical and biological properties, but that land restoration practices through longer fallow period (>10 years) likely are successful in promoting the recovery of some soil characteristics.
\end{abstract}

Keywords: Land Use, Oil palm plantation, Organic matter, Rubber Plantation, Soil fertility

\section{INTRODUCTION}

Soil modification due to changes in land use types and patterns is a major threat to sustainable productivity of the soil (Ayoubi et al., 2011) and is considered one of the major factors that affect the distribution patterns of nutrients (Islam and Weil, 2000 ) in the soil. Northeastern India is drastically affected by land use change (Grogan et al., 2012; Tao et al., 2018), particularly, shifting cultivation, closely linked to ecological, socio-economic, cultural and land tenure systems of tribal communities (Tripathi et al., 2017) profoundly affects the soil fertility and crop productivity (Wapongnungsang et al., 2018).

Mizoram, a region with steep slopes hills in Northeast India have undergone different land use change (Lallianthanga and Hmingthanpuii, 2013; Lallianthanga et al., 2014) with more than $60 \%$ of the total population depending on small scale agricultural practices as it is the main source of liveli- hood for rural areas. The significant reduction in Jhum area is mainly due to the implementation of Oil Palm and Rubber plantation. Out of the total geographical area i.e., 2108700 hectare, the total potential area for Oil palm plantation was recorded as 101000 hectare. Rubber Plantation of about 1000 hectare is also established at different districts of the state (Economic survey Mizoram, 2016-2017). Bamboo forest covering $57 \%$ of the total geographical area has shown a positive impact both in terms of forest cover and livelihood (MIRSAC, 2007).

SOC is an important component of the global carbon cycle indicating soil fertility and productivity (Van der Werf et al., 2009) and studies have shown a significant variation with relation to land uses (Ali et al., 2017; lqbal et al., 2014; Maurya et al., 2014). The land use practices often influences the fluxes of soil carbon stocks and have been reported to vary with the change in land use systems. Various studies have reported a strong de- 
crease of SOC after forest conversion to plantations (Guillaume et al., 2015; van Straaten et al., 2015). This has led to raise major concerns about the sustainability of such land use types in the tropics (Lal, 2010).

Although several studies have already been reported related to shifting agriculture (Hauchhum and Tripathi, 2017; Wapongnungsang, 2017; Wapongnungsang et al., 2018), however, the impact of land use change and plantations on soil physicochemical and biological properties is poorly understood. Therefore, the present study aims to investigate the soil properties in five different land use systems, namely, Rubber Plantation, Oil Palm Plantation, Bamboo Forest, Fallow land ( 20 yrs) and Natural Forest.

\section{MATERIALS AND METHODS}

Site description: Five different land use systems were selected from Mizoram, namely, Rubber Plantation (RP) $\left(23^{\circ} 47.123^{\prime} \mathrm{N}\right.$ lat and 92 $36.831^{\prime}$ E long), Oil Palm Plantation (OPP) (2347.559' N lat and $92^{\circ} 36.492^{\prime} \mathrm{E}$ long), Bamboo Forest (BF) $\left(23^{\circ} 47.771^{\prime} \mathrm{N}\right.$ lat and $92^{\circ} 36.080^{\prime} \mathrm{E}$ long), Fallow land $(\sim 20 \mathrm{yrs})(\mathrm{FL})\left(23^{\circ} 35.392^{\prime} \mathrm{N}\right.$ lat and $92^{\circ}$ 42.952' $\mathrm{E}$ long) and Natural Forest (NF) $\left(23^{\circ}\right.$ $35.207^{\prime} \mathrm{N}$ lat and $92^{\circ} 43.016^{\prime} \mathrm{E}$ long). Three replicated plots $(20 \mathrm{~m} \times 25 \mathrm{~m})$ were established for each land use type to consider true site replicates by maintaining the minimum distance between plots with more than $15 \mathrm{~m}$ (Mariotte et al., 1997). All the studied land uses experiences moderate humid tropical climate (MIRSAC, 2007).

Soil sampling: Soils were collected from three replicated plots within each land use type following the simple random sampling technique. Soil auger was used to collect the soil samples from 10 different subplots within each replicated plots and further pooled as composite sample. Roots, stones, and debris if any, were removed and hand sieved through a $2 \mathrm{~mm}$ mesh sieve and separated into two parts. One part was air dried and the other part was kept in the deep freezer for further analysis.

Analysis of soil properties: Soil Bulk density (BD) was measured by collecting a known volume of soil using a metal ring pressed into the soil (intact core), and determining the weight after drying (McKenzie et al., 2002). Soil texture was determined following the hydrometer method (Bouyoucos, 1962). The textural classification according to the United States Department of Agriculture (USDA) was followed to give the textural class of soil. Soil $\mathrm{pH}$ was measured in a soil-water suspension (1:2.5 soil-water ratios) with $\mathrm{pH}$ analyzer. The gravimetric method was followed to determine soil moisture content (SMC). Soil organic carbon (SOC) and total nitrogen (TN) was determined by dry combustion in a CHNS/O Elemental Analyzer with autos ampler and TCD de- tector -Euro Vector, Model: EuroEA3000. Ammonium nitrogen $\left(\mathrm{NH}_{4}{ }^{+}-\mathrm{N}\right)$ was estimated by Indophenol-blue method (Rowland, 1983) and Nitrate-nitrogen $\left(\mathrm{NO}_{3}^{-}-\mathrm{N}\right)$ by Phenol disulphonic acid method (Harper, 1924). Soil Microbial Biomass Carbon (SMBC) was determined by following the fumigation extraction method (Vance et al., 1987). Oven-dry equivalent field-moist soil $(25 \mathrm{~g})$ was fumigated for $24 \mathrm{~h}$ at $25^{\circ} \mathrm{C}$ with ethanol-free $\mathrm{CHCl}_{3}$. Following fumigant removal, the soil was treated with $100 \mathrm{ml}$ of $0.5 \mathrm{M} \mathrm{K}_{2} \mathrm{SO}_{4}$ by horizontal shaking for $1 \mathrm{~h}$ and then filtered. The other non fumigated $25 \mathrm{~g}$ soil was extracted simultaneously. $\mathrm{MBC}$ was calculated using $\mathrm{k}_{\mathrm{EC}}$ factor of 0.38 (Vance et al., 1987). Soil basal respiration was estimated following the Alkali absorption method (AA-method) (Kirita, 1971).

\section{RESULTS AND DISCUSSION}

The studied soil physical properties were found significantly different across the land use systems $(p<0.05)$ and the values are shown in Table 1. Bulk density (BD) values ranged from $1.06 \mathrm{~g} / \mathrm{cm}^{3}$ $-1.27 \mathrm{~g} / \mathrm{cm}^{3}$ with maximum density in RP which was followed by OPP $>N F>F L>B F$. The minimum bulk density in $\mathrm{BF}$ soils could be due to profuse root growth and dense root distribution in BF compared to other land uses. The conversion of the natural forest to plantations probably lead to loss of soil organic matter (SOM) that caused higher bulk density in the plantation soils. Higher bulk densities under intensive rubber plantation were previously reported in Indonesia (Allen et al., 2015; Guillaume et al., 2015). The soil texture of all the land use was determined to be sandy loam with sand, silt and clay values ranging from $62.5 \%$ - $71.2 \%, 17.0 \%-20.6 \%$ and $11.8 \%-16.9 \%$ respectively. High sand percent was estimated from BF soils and clay percent was high in plantation soils compared to other land uses.

The soils were found to be acidic in nature with a narrow $\mathrm{pH}$ range among the land use systems. Soil $\mathrm{pH}$ and moisture content values ranged from 3.9 to 4.9 and $17.4 \%$ to $23.4 \%$ respectively (Table 1). The NF soil was highly acidic compared to RP, BF, OPP and FL. Similarly, the moisture content was also higher in NF soils. High organic matter content and dense vegetation in NF probably conserve the soil moisture. It has been reported that forest conversion to plantations in Indonesia, Peru and Southern Cameroon led to low moisture availability due to losses in the top soil and vegetation (van Straaten et al., 2015; Guillaume et al., 2016). The values of SOC and TN were found higher in NF followed by FL, BF, OPP and RP (Table 1) and the values ranged from $2.02 \%$ to $2.81 \%$ and $0.22 \%$ to $0.3 \%$ respectively. High SOC in NF can be accounted by a considerable amount of litter decomposition and availability of soil nutrients. The higher inputs of organic matter and nutrients 
Table 1. Soil properties of different land use systems. Values are mean $\pm 1 S E(n=5)$. LSD is shown at $p<0.05$.

\begin{tabular}{|c|c|c|c|c|c|c|}
\hline \multirow[b]{2}{*}{ SOIL VARIABLES } & \multicolumn{6}{|c|}{ LAND USE SYSTEMS } \\
\hline & $\begin{array}{l}\text { Rubber Plan- } \\
\text { tation }\end{array}$ & $\begin{array}{l}\text { Bamboo } \\
\text { Forest }\end{array}$ & $\begin{array}{l}\text { Oil Palm } \\
\text { Plantation }\end{array}$ & $\begin{array}{l}\text { Fallow } \\
\text { Land }\end{array}$ & $\begin{array}{l}\text { Natural For- } \\
\text { est }\end{array}$ & LSD \\
\hline Bulk Density & $1.27 \pm 0.04$ & $1.06 \pm 0.01$ & $1.16 \pm 0.02$ & $1.09 \pm 0.01$ & $1.10 \pm 0.004$ & 0.18 \\
\hline Sand (\%) & $62.5 \pm 0.10$ & $71.2 \pm 0.99$ & $63.7 \pm 2.08$ & $68.6 \pm 0.05$ & $69.2 \pm 1.91$ & 4.23 \\
\hline Silt (\%) & $20.6 \pm 0.04$ & $17.0 \pm 0.94$ & $19.6 \pm 1.63$ & $17.8 \pm 0.55$ & $18.8 \pm 0.78$ & 2.97 \\
\hline Clay (\%) & $16.9 \pm 0.05$ & $11.8 \pm 1.94$ & $16.7 \pm 0.45$ & $13.6 \pm 0.6$ & $12.0 \pm 1.13$ & 3.34 \\
\hline Soil pH & $4.68 \pm 0.05$ & $4.91 \pm 0.08$ & $4.65 \pm 0.14$ & $4.84 \pm 0.07$ & $3.93 \pm 0.12$ & 0.31 \\
\hline Soil Moisture (\%) & $20.3 \pm 0.7$ & $21.3 \pm 1.0$ & $17.4 \pm 1.14$ & $22.3 \pm 0.6$ & $23.4 \pm 0.11$ & 2.88 \\
\hline Soil Carbon (\%) & $2.02 \pm 0.15$ & $2.32 \pm 0.05$ & $2.22 \pm 0.14$ & $2.36 \pm 0.15$ & $2.81 \pm 0.1$ & 0.38 \\
\hline Total Nitrogen (\%) & $0.22 \pm 0.01$ & $0.23 \pm 0.01$ & $0.23 \pm 0.007$ & $0.26 \pm 0.008$ & $0.3 \pm 0.11$ & 0.06 \\
\hline Ammonium (mg/kg) & $7.34 \pm 0.88$ & $10.2 \pm 1.5$ & $7.58 \pm 1.3$ & $5.60 \pm 0.46$ & $8.96 \pm 0.8$ & 3.14 \\
\hline Nitrate $(\mathrm{mg} / \mathrm{kg})$ & $1.25 \pm 0.36$ & $1.94 \pm 0.5$ & $2.81 \pm 0.14$ & $1.15 \pm 0.13$ & $2.81 \pm 0.3$ & 1.03 \\
\hline $\begin{array}{l}\text { Soil Microbial Biomass } \\
\text { Carbon }(\mathrm{mg} / \mathrm{kg})\end{array}$ & $341.9 \pm 10.31$ & $340 \pm 12.3$ & $341.2 \pm 12.3$ & $343.4 \pm 3.6$ & $345.2 \pm 15.0$ & 31.8 \\
\hline $\begin{array}{l}\text { Soil Respiration } \\
\left(\mathrm{mgCO}_{2} / \mathrm{m}^{2} / \mathrm{hr}\right)\end{array}$ & $375 \pm 39.5$ & $224.1 \pm 42.8$ & $372.9 \pm 30.2$ & $345.2 \pm 31.3$ & $345.4 \pm 35.7$ & 106 \\
\hline
\end{tabular}

through litter fall have positively shown to affect soil organic matter (Hattori et al., 2005; Ouyang et al., 2007). SOC availability is a good indicator of soil nutrient supply in tropical ecosystems (Chen et al., 2010). It has been reported that soil erosion is the factor affecting the SOC loss in oil palm plantations of Peninsular Malaysia (Gharibreza et al., 2013). In contrast to other land use, less SOC in OPP may be due to the effect of land management activities under plantation. The regular clearance of the surface through weeding and removal of the fallen leaves leads to low microbial activity. Available forms of nitrogen play an important role in $\mathrm{N}$ transformation. The values of $\mathrm{NH}_{4}{ }^{+}-\mathrm{N}$ and $\mathrm{NO}_{3}{ }^{-}-\mathrm{N}$ ranged from $5.6 \mathrm{mg} \mathrm{kg}^{-1}$ to $10.2 \mathrm{mg} \mathrm{kg}^{-1}$ and $1.15 \mathrm{mg} \mathrm{kg}^{-1}$ to $2.81 \mathrm{mg} \mathrm{kg}^{-1}$ respectively. Higher range of $\mathrm{NH}_{4}{ }^{+}-\mathrm{N}$ and $\mathrm{NO}_{3}{ }^{-} \mathrm{N}$ in NF soils depicted higher rate of ammonification and nitrification which were favoured by high soil moisture content in NF. Results suggested that soil moisture stimulated the soil microbial activity, as also observed in natural and regenerated tropical forests soils of Brazil (Silva et al., 2012).

The values of soil microbial biomass carbon (SMBC) in the land use types ranged from $340 \mathrm{mg}$ $\mathrm{kg}^{-1}$ to $345 \mathrm{mg} \mathrm{kg}^{-1}$. NF soils exhibited the maximum SMBC whereas the minimum was observed in BF. Several workers have found a close relationship between soil moisture and microbial biomass (Devi and Yadava, 2006; Singh et al., 2010). Results showed that SMBC were greatly influenced by SOC. Several reports (Chen et al., 2005; Chen et al., 2017) have shown that higher SOC enhances the growth of microbes and causes accumulation of microbial biomass in soil.

The change in soil respiration rates due to soil temperature and moisture under climate change often contributes to the responses of soil respiration in different ecosystems. Basal respiration in BF was significantly different $(p<0.05)$ compared to other land uses with highest in RP followed by
$\mathrm{OPP}>\mathrm{NF}>\mathrm{FL}$ and lowest in $\mathrm{BF}$. The values ranged from 224 to $375 \mathrm{mg} \mathrm{CO}_{2} \mathrm{~m}^{-2} \mathrm{hr}^{-1}$ (Table 1). The greater soil microbial activity in RP, OPP and NF could release more nutrients from soil organic matter for fine root uptake which further lead to increase in soil respiration compared to FL and BF. Guntinas et al. (2013) reported that higher moisture content in the soils of forest, grassland and cropland is responsible for higher soil respiration rate. Low SMBC and basal respiration in BF indicates the proliferation of profuse root systems in $\mathrm{BF}$ as to exploit soil nutrients from the greater volume of soil to compensate high productivity of BF.

\section{Conclusion}

This study highlights the soil properties of different land use types of Mizoram. Results showed a distinct change in soil properties with the land use change ultimately leading to negative feedbacks between soil property and land use types. It further indicated that land use change to RP and OPP deteriorated native soil physicochemical and biological properties, but land restoration practices through longer fallow period (>10 years) are likely to promote the recovery of inherent soil characteristics. However, a long term observation of the land use change is recommended for further study to follow in order to understand the chrono sequence effect of land use change.

\section{REFERENCES}

1. Ali, S., Begum, F., Hayat, R. and Bohannan, B. J. M, (2017). Variation in soil organic carbon stock in different land uses and altitudes in Bagrot Valey, Northern Karakoram, Acta Agr. Scand B-S P, 551-561. https:// doi.org/10.1080/09064710.2017.1317829

2. Allen, K., Corre, M. D., Tjoa, A. and Veldkamp, E. (2015). Soil nitrogen-cycling responses to conversion of lowland forests to oil palm and rubber plantations in Sumatra, Indonesia. PLoS One, 10: e0133325. https://doi.org/10.1371/journal.pone.0133325

3. Ayoubi, S., Khormali, F., Sahrawat, K. L. and Ro- 
drigues de Lima, A. C. (2011). Assessing Impacts of Land Use Change on Soil Quality Indicators in a Loessial Soil in Golestan Province, Iran. J. Agr. Sci. Tech., 13:727-742.

4. Bouyoucos, G.J. (1926). Estimation of the colloidal material in soils. Soil Sci. 64: 362. https:// doi.org/10.1126/science.64.1658.362

5. Chen, C., Liua, W., Jiang, X. and Wua, J. (2017). Effects of rubber-based agroforestry systems on soil aggregation and associated soil organic carbon: Implications for land use. Geoderma, 299:13-24. https:// doi.org/10.1016/j.geoderma.2017.03.021

6. Chen, T. H., Chiu, C. Y. and Tian, G. L. (2005). Seasonal dynamics of soil microbial biomass in coastal sand dune forest. Pedobiologia, 49: 645-653. https://doi.org/10.1016/j.pedobi.2005.06.005

7. Chen, X. M., Liu, J. X., Deng. Q., Chu, G. W., Zhou, G. Y. and Zhang, D. Q. (2010). Effects of precipitation intensity on soil organic carbon fractions and their distribution under subtropical forests of South China. Chin. J. Appl. Ecol., 21(5):1210-6.

8. Devi, N. B. and Yadava, P. (2006). Seasonal dynamics in soil microbial biomass $\mathrm{C}, \mathrm{N}$ and $\mathrm{P}$ in a mixedoak forest ecosystem of Manipur, North-East India. Appl. Soil Ecol., 31: 220-227. https://doi.org/10.1016/ j.apsoil.2005.05.005

9. Economic Survey Mizoram, (2016-17.) Government of Mizoram. Planning \& Programme Implementation Department (Research \& Development Branch) pp. 243-245.

10.Gharibreza, M., Raj, J. K., Yusoff, I., Othman, Z., Tahir, W. Z. and Ashraf, M.A. (2013). Land use changes and soil redistribution estimation using $137 \mathrm{Cs}$ in the tropical Bera Lake catchment, Malaysia. Soil Tillage Res., 131:1-10. https://doi.org/10.1016/ j.still.2013.02.010

11.Grogan, P., Lalnunmawia, F. and Tripathi, S. K. (2012). Shifting cultivation in steeply sloped regions: A review of management options and research priorities for Mizoram state, Northeast India. Agrofor. Syst., 84:163-177. https://doi.org/10.1007/s10457011-9469-1

12.Guillaume, T., Damris, M. and Kuzyakov, Y. (2015). Losses of soil carbon by converting tropical forest to plantations: erosion and decomposition estimated by $\delta$ (13) C. Glob. Chang. Biol., 21:3548-3560. https:// doi.org/10.1111/gcb.12907

13.Guillaume, T., Maranguita, D., Murtilaksono, K. and Kuzyakov, Y. (2016). Sensitivity and resistance of soil fertility indicators to land-use changes: new concept and examples from conversion of Indonesian rainforest to plantations. Ecol. Indic., 67:49-57. https://doi.org/10.1016/j.ecolind.2016.02.039

14.Guntinas, M. E., Gil-Sotres, F., Leiros, M. C. and Trasar-Cepeda, C. (2013). Sensitivity of soil respiration to moisture and temperature. J. Soil Sci. Plant Nutr., 13(2):445-461

15. Harper, H. J. (1924). The accurate determination of nitrates in soils. Ind. Eng. Chem. Res., 16:180-183.

16. Hattori, D., Sabang, J., Tanaka, S., Kendawang, J. J., Ninomiya, I. and Sakurai, K. (2005). Soil characteristics under three vegetation types associated with shifting cultivation in a mixed dipterocarp forest in Sarawak, Malaysia. Soil Sci. Plant Nutr., 51: 231241. 0765.2005.tb00027.x

17. Hauchhum, R. and Tripathi, S. K. (2017). Rhizo- sphere effects of Melocanna baccifera on soil microbial properties under different fallow phases following shifting cultivation. IJPSS, 17:1-9. https:/l doi.org/10.9734/IJPSS/2017/34493

18.lqbal, M. A., Hossen, M. S. and Islam, M. N. (2014). Soil organic carbon dynamics for different land uses and soil management practices in Mymensingh. Proceedings of 5th International Conference on Environmental Aspects of Bangladesh; Bangladesh. 16-17.

19.Islam, K. R. and Weil, R. R. (2000). Land use effects on soil quality in a tropical forest ecosystem of Bangladesh. Agric. Ecosyst. Environ., 79: 9-16. https:// doi.org/10.1016/S0167-8809(99)00145-0

20.Kirita, H. (1971). Re-examination of the absorption method for measuring soil respiration under field conditions, IV. An improved absorption method using a disc of plastic sponge as absorbent holder. Jpn. $J$. Ecol., 21:119-127.

21.Lal, R. (2010). Enhancing eco-efficiency in agroecosystems through soil carbon sequestration. Crop Sci., 50:120-131. https://doi.org/10.2135/ cropsci2010.01.0012

22.Lallianthanga, R. K. and Hmingthanpuii. (2013). Integrated Land Use Planning of Aizawl District, Mizoram, India Using Geospatial Techniques. International Journal of Advanced Remote Sensing and GIS, 2 (1): 341-350.

23.Lallianthanga, R. K., Sailo, R. L., Hmingthanpuii and Lalhmachhuana, H. (2014). Land Use Planning for Lawngtlai District, Mizoram, India: A Remote Sensing and GIS perspective. Int. J. Curr. Res. Aca. Rev., 2 (3):42-53.

24.Mariotte, C. A., Hudson, G. and Hamilton, D. (1997). Spatial variability of soil total $\mathrm{C}$ and $\mathrm{N}$ and their stable isotopes in upland Scottish grassland. Plant Soil, 196:151-162.

25.Maurya, B., Singh, V., Dhyanib, P. and Kashyap, S. (2014). Impact of altitudes on soil characteristics and enzymatic activities in the forest and Fallow lands of Almora District of Central Himalaya. Oct. Jour. Env. Res., 2: 1-9.

26.McKenzie, N., Coughlan, K. and Cresswell, $H$. (2002). Soil physical measurement and interpretation for land evaluation. CSIRO Publishing: Collingwood, Victoria.

27.MIRSAC, (2007). Natural Resources Mapping of Mizoram using Remote Sensing and GIS, Aizawl District (A Project Report). Mizoram Remote Sensing Application Centre, Science Technology \& Environment, Aizawl. pp. 2-37.

28.Ouyang, X. J., Zhou, G. Y., Wei, S. G., Huang, Z. L., $\mathrm{Li}, \mathrm{J}$. and Zhang, D. (2007). Soil organic carbon and nitrogen mineralization along a forest successional gradient in Southern China. Chin. J. App.I Ecol., 18: 1688-1694.

29. Rowland, A. P. (1983). An automated method for the determination of Ammonium- $\mathrm{N}$ in ecological materials. Commun. Soil Sci. Plant Anal., 14: 49-63. https:// doi.org/10.1080/00103628309367341

30.Silva, D. K. A., Freitas, N. O., Sousa, R. G., Silva, F. S. B., Araújo, A. S. F. and Maia, L. C. (2012). Soil microbial biomass and activity under natural and regenerated forests and conventional sugar-cane plantations in Brazil. Geoderma, 189: 257-261. https://doi.org/10.1016/j.geoderma.2012.06.014

31.Singh, J. S., Singh, D. P. and Kashyap, A. K. (2010). Microbial biomass $\mathrm{C}, \mathrm{N}$ and $\mathrm{P}$ in disturbed dry tropi- 
cal forest soils, India. Pedosphere, 20(6): 780-788. https://doi.org/10.1016/S1002-0160(10)60068-9

32.Tao, D.L., Singh, N.J. and Goswami, C. (2018). Spatial Variability of Soil Organic Carbon and Available Nutrients under Different Topography and Land Uses in Meghalaya, India. IJPSS, 21: 1-16. https:// doi.org/10.9734/IJPSS/2018/39615

33.Tripathi, S. K., Vanlalfakawma, D. C. and Lalnunmawia, F. (2017.) Shifting cultivation on steep slopes of Mizoram, India: Impact of policy reforms. In: Cairns M. (ed.), Shifting Cultivation Policies: Balancing Environmental and Social Sustainability: $\mathrm{CABI}$ Publishing, London, 395- 413.

34.Van der Werf, G.R., Morton, D. C., De Fries, R. S., Olivier, J. G. J., Kasibhatla, P. S., Jackson, R. B., Collatz, G. J. and Randerson, J. T. (2009). $\mathrm{CO}_{2}$ Emissions from Forest Loss. Nature Geoscience, 2: 737-738. http:// doi.org/10.1038/ngeo671

35.van Straaten, O., Corre, M. D., Wolf, K., Tchienkoua,
M., Cuellar, E., Matthews, R. B. and Veldkamp, E. (2015). Conversion of lowland tropical forests to tree cash crop plantations loses up to one-half of stored soil organic carbon. PNAS, 112(32): 9956-9960. https://doi.org/10.1073/pnas.1504628112

36.Vance, E. D., Brookes, P. C. and Jenkinson, D. S. (1987). An extraction method for measuring soil microbial biomass C. Soil Biol. Biochem., 19: 703-707. https://doi.org/10.1016/0038-0717(87)90052-6

37.Wapongnungsang, Hauchhum, R. and Tripathi, S. K. (2017). Litter decomposition Vis-a-Vis carbon and nitrogen dynamics of Tephrosia candida components in different fallow periods following shifting cultivation in Mizoram. Indian J. Ecol., 44(4):791-796.

38.Wapongnungsang, Manpoong, C. and Tripathi, S. K. (2018). Changes in soil fertility and rice productivity in three consecutive years cropping under different fallow phases following Shifting cultivation. IJPSS, 25 (6):1-10. https://doi.org/10.9734/IJPSS/2018/46087 